University of Rhode Island

DigitalCommons@URI

Open Access Master's Theses

1988

\title{
The Effects of Open and Dominant Communication Styles on Perceptions of the Sales Interaction
}

\author{
Elaine M. Notarantonio \\ University of Rhode Island
}

Follow this and additional works at: https://digitalcommons.uri.edu/theses

\section{Recommended Citation}

Notarantonio, Elaine M., "The Effects of Open and Dominant Communication Styles on Perceptions of the Sales Interaction" (1988). Open Access Master's Theses. Paper 1674.

https://digitalcommons.uri.edu/theses/1674

This Thesis is brought to you for free and open access by DigitalCommons@URI. It has been accepted for inclusion in Open Access Master's Theses by an authorized administrator of DigitalCommons@URI. For more information, please contact digitalcommons-group@uri.edu. 
THE EFFECTS OF OPEN AND DOMINANT COMMUNICATION STYLES ON PERCEPTIONS OF THE

SALES INTERACTION

BY

ELAINE M. NOTARANTONIO

A THESIS SUBMITTED IN PARTIAL FULFILIMENT OF THE REQUIREMENTS FOR THE DEGREE OF

MASTER OF ARTS

IN

PSYCHOLOGY

UNIVERSITY OF RHODE ISLAND

1988 
ABSTRACT

This study empirically tests whether or not different communication styles affect sales effectiveness using the Open and Dominant styles from Norton's (1978) dimensions.

It was hypothesized that the more open a salesperson is, the more effective the individual will be in selling the product. It was also hypothesized that the more Dominant the salesperson is the more effective $s /$ he will be.

Four groups of students saw videotapes of a sales interaction. Each tape depicted one of the four communicator style types (combinations of high and low levels of Dominance and openness). The tapes were first pretested on small groups of subjects to ensure the adequacy of the manipulation. The experiment involved 80 subjects viewing the tape after which they completed a 42-item questionnaire. Six composite scores were identified from groups of questions that were a priori related. Separate two-way ANOVAs for each measure were run with Openness and Dominance as independent variables for the measures of openness and dominance and the six composite measures. Four of these composites showed significance; perceptions of the product being sold, the interaction between the salesperson and customer in the tape, probability of purchase of the product in the tape and perceptions of the salesperson being depicted in the tape.

For the open construct, subjects in the high Dominant group saw the salesperson as more open than those in the low 
Dominant group. For the dominant measure, subjects in the high open condition viewed the salesperson as significantly more dominant than those in the low open condition. Likewise, subjects in the high Dominant condition viewed the salesperson as more dominant than those in the low Dominant condition. Respondents, in general, rated the high Dominant/low open and low Dominant/high open conditions more favorable than the high Dominant/high open or low Dominant/low open.

Since communication style in a marketing context remains a new field of investigation, there are several directions in which future research can move. 


\section{ACKNOWLEDGEMENT}

I would like to express my sincere gratitude and appreciation to the members of my Thesis committee; Dr.Jerry Cohen, Dr. Greg Lessne, Dr. Paul Florin and Dr. Norman Coates for their support during the preparation and defense of this thesis.

Dr. Cohen, my major professor has been most outstanding in his patience, teaching, listening, flexibility and understanding during one of the most difficult periods of my life. The learning which I've gained as a result of working under his direction is incomparable. 
TABLE OF CONTENTS

Page

List of Tables-_-_- vi

Introduction and Background--_-_--- 1

Method--_-_-_-_-_-_-_- 8

Apparatus---_---_--_-_- 8

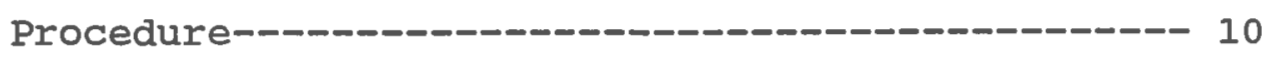

Results--- 11

Discussion--_-_-_-_-_-_-_-_- 14

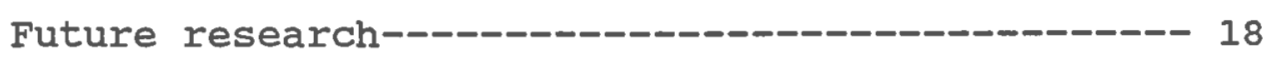

Table 1--

Table 2-D-- 23

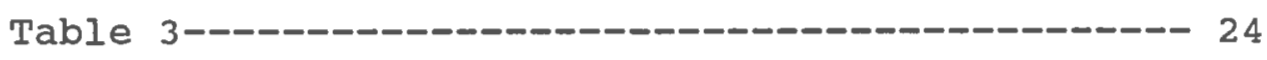

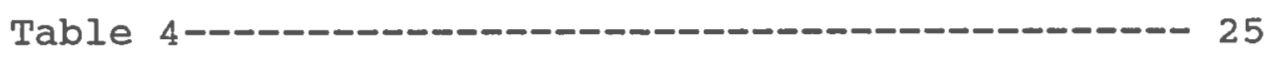

References--D-D-- 26

Appendix A----- 29

Appendix B----- 45

Bibliography-- 54 . 


\section{LIST OF TABLES}

1. Composite measures and questionnaire items----------20

2. Cell means for the measure of Dominance in the Dominant $x$ openness interaction--------------------------------23

3. Cell means for the composite of PROD in the Dominant $x$ openness interaction-

4. Pearson product moment correlation coefficients for composite measures---- 
The Effects of Open and Dominant Communication Styles on Perceptions of the Sales Interaction

Norton (1978) has established a foundation for a "communicator style" construct. He defines communicator style as the way in which a person verbally and paraverbally interacts to signal how literal meaning should be taken, interpreted, filtered or understood. He operationally defines the communicator style domain in terms of ten independent variables and one dependent variable. The independent variables or subconstructs are: (1) impressionleaving, (2) contentious, (3) open, (4) dramatic, (5) dominant, (6) precise, (7) relaxed, (8) friendly, (9) attentive, and (10) animated. The dependent variable, also a subconstruct, is communicator image and is included in the domain as an overall assessment of communicator ability. Communicator style is assumed to be different from personality in that it can be deliberately manipulated by the communicator (Norton and Nussbaum 1980).

Two primary lines of research have produced substantial empirical evidence for the reliability and validity of the communicator style construct (Bednar, 1982). One has focused upon the detailed analysis of each of the eleven components which comprise the style domain. To date, four of these have been explicated in some detail: the dramatic (Norton, Clarke, Sypher, and Brady, 1977; Norton, Baker, Bednar, Salyer, and McGough, 1978), the open (Norton and Montgomery, 1979), the relaxed (Emery, Norton and Plain, 1980), and the 
attentive (Norton and Pettegrew, 1977). The second line of research has focused upon relationships between communicator style and various perceptual processes and interpersonal consequences. Some topics that have been addressed include: teacher effectiveness (Norton, 1977; Norton and Nussbaum, 1980), dyadic perception of communicator style (Norton and Miller, 1975), the personnel selection interview (Norton and Bednar, 1979; Norton and Robinson, 1980), communicator style as an effective determinant of attraction (Norton and Pettegrew, 1977), sex differences in self-reported communicator style (Montgomery and Norton,1979, Staley \& Cohen, 1988), the impact of communicator style in therapeutic relationships (Pettegrew, 1977), and relationships between communicator style and managerial performance (Bednar, 1982). All of these studies are characterized by the use of Norton's construct as a guiding framework.

In the selling process, exchange is typically initiated, maintained and terminated on a person-to-person basis. The salesperson's most basic activity during this exchange is communication. In the competitive marketplace, effective communication is of paramount importance. It is no exaggeration to say that the salesperson is the most important communicator in the entire organization. All other efforts are of no avail if the salesperson is unable to communicate in a manner that induces purchase. For the firm to achieve full promotional impact in the marketplace, the salesperson must be an effective communicator. Insight into 
the communication process is therefore of vital importance. In spite of this, communication has received little attention in personal selling research (Capon, Holbrook, and Hulbert, 1977).

Most of the early empirical work related to personal selling examined the personal characteristics of the salesperson. Several later studies have examined communication content followed by communication code, rules and to some extent style. In marketing, those studies that have considered communication style have done so indirectly.

Pace (1961) examined the relationship between oral communication and sales effectiveness. An objective observer rated two groups of salespeople who had been differentiated into an effective "high" group and a less effective "low" group. These groups were compared in terms of selected aspects of their sales behavior. The results show that the more effective salespeople were rated higher than the less effective ones in terms of overall impression of communication skill. This suggests that oral communication skill is likely to be a reliable criterion for differentiating superior from inferior salespeople. Also, sales methods such as using "emotional appeals" and "dramatizing" distinguished between the more effective and the less effective salespeople.

Sheth (1976) suggests a paradigm where customers and salespeople can be characterized according to their communication styles as task-oriented, interaction-oriented 
or self-oriented. Sheth's conceptualization of the customer/salesperson communication style is based on a framework of leadership style suggested by Bass $(1960,1967)$. Accordingly, this model presumes communication style to be three dimensional, consisting of a task orientation, a self orientation, and an interaction orientation. The taskoriented style is highly goal oriented and purposeful. The salesperson using this style is concerned with efficiency and minimizing time, cost and effort. The self-oriented salesperson is preoccupied with him or herself in an interaction, and more concerned about his own welfare and less empathetic toward the other person.

williams and Spiro (1985) conducted an exploratory study which first developed scales to measure the communication style variable in personal selling and then tested whether the styles affected sales outcome. Williams and spiro draw on Sheth's (1976) model of the buyer/seller interaction; the scale items developed were more specific to the sales interaction context than those from the general Bass inventory. Importantly, like the questionnaire items used in the present study, Williams \& Spiro's items measured each person's perception of the other's style. Most studies of salesperson and/or customer behavior have used self-report measures.

The results of the williams \& Spiro (1985) study show that communication styles as measured by task, self and interaction orientation scores were significant in terms of 
explaining sales variance. This finding supports the notion that communication style be considered as one of the dimensions affecting sales outcome. Second, this study highlights the overriding importance of the customer's orientation. This suggests that the salesperson who recognizes different customer styles and adapts his or her communication style accordingly, is more likely to be successful.

The present study utilizes Norton's communication style dimensions in terms of perceived communicator style and sales effectiveness. These dimensions somewhat parallel those used by Sheth (1976); the specific dimensions employed were Dominance and openness. Respondents were independent observers of a sales interaction. A number of studies ( e.g. Pace (1961)) of communicator style have taken this approach (i.e. utilizing independent observers in order to examine perceptions).

Bednar (1982) looked at the degree to which perceived communicator style characteristics of organizational managers and supervisors systematically covary with their performance. Independent evaluations of communicator style and performance were obtained for 105 managers from two different organizations. "Outstanding" and "definitely above average" managers in terms of performance, were perceived by superiors, subordinates and peers as qualitatively different in certain aspects of their communicator style.

Graetz (1974) also used independent observers in a study 
of relationships between aspects of verbal behavior of supermarket store managers and their managerial

effectiveness. Since communicator style is something that is assumed to be deliberately manipulated by the communicator; it is postulated that, in a sales situation, a salesperson can manipulate his/her style to provide for maximum sales effectiveness. The Dominance and openness dimensions are believed to be applicable to a sales situation and were closest to those described by Williams and spiro (1985). In addition, Bushard (1959) observed that enlisted men in small military units (eight to ten man squads) after brief exposures and limited interactions could be differentiated by communication patterns. The most dominant persons were quite talkative, outgoing, and aggressive. These individuals possessed the greatest social skill and as a result maintained prominent positions.

Hayes and Meltzer (1972) found that persons who talk a great deal or very little are rated unfavorably and they are described as having predominantly unpleasant attributes. They contend that the most favorable evaluations are given to persons who contribute somewhat more than their share to the conversation and that there probably is an optimal level of talkativeness in which the person is perceived by the others in the most favorable light. Talkativeness seems to be analogous to Norton's openness dimension.

The dominant salesperson responds longer and louder with less compliance and more requests for the other (customer) to 
change his or her behavior. S/he appears to be more competitive, confident, enthusiastic, forceful (Norton 1978). This seems very closely aligned with the task-oriented salesperson as described by williams and spiro (1985). In addition, Bass (1960) describes the task-oriented leader as one who is goal-oriented, who overcomes barriers and who persists.

The open communicator is characterized by styles that are conversational, gregarious, unsecretive and frank. The communicator reveals personal information about him or herself. The self-oriented salesperson is also preoccupied with self during an interaction.

Accordingly, our research empirically tests whether or not different communication styles affect sales effectiveness. The present study attempts to examine this using the Open and Dominant styles from Norton's dimensions. Four combinations of communicator style were generated by combining the Dominant and open subconstructs. The four unique combinations of style variables used to operationally define the types of communicator style were: high Dominant/high open, high Dominant/low Open, low Dominant/high Open, and low Dominant/low open. It was hypothesized that the more open a salesperson is, the more effective the individual will be in selling the product and the more positively s/he will be perceived by others. It was also hypothesized that the more dominant the salesperson, the more effective $s /$ he 
will be. These variables may also interact but no specific effects are predicted.

Method

\section{Subjects}

Subjects consisted of undergraduate Business Administration students enrolled at Bryant College. Eighty subjects participated in the study. A demographic analysis revealed that $41.3 \%$ of the respondents were male and $58.7 \%$ were female. Students ranged in age from 17 to 21 years with 73\% of subjects being 18 years of age. Freshman accounted for $92.1 \%$ of the sample.

\section{Apparatus}

Four videotapes were produced. Openness was manipulated by varying the degree to which the salesperson talked about himself. Dominance was manipulated by varying the degree of persuasiveness and monopolizing of the conversation. Communication content did not differ among the conditions (See Appendix A for scripts of the tape). Each of the tapes depicts one of the four communicator style types. The hypothetical product being sold in all tapes was a programmable stereo system where one can punch in a 5-digit code corresponding to a desired song. The tape simulated a trade show in which a booth was manned by the salesperson. The scenario involved the customer approaching the booth to view the product after which the sales interaction began and was varied depending upon the condition. The customer in the tape remained neutral and did not vary his style among 
conditions. It was the salesperson whose style was manipulated. Both actors were male and approximately twenty years of age. The salesperson was above average in height and the customer below average. Each tape was approximately four minutes in length.

Each of the four videotapes were pretested by showing them to small groups of subjects $(n=10)$. Respondents were then asked to complete a communicator style measure which included measures of openness and dominance. These measures were seven-point scales of agreement with the value of 7 indicating strong agreement of possessing the trait. This was done in order to ensure that. the communicator style being depicted on the tape was actually being perceived by the subjects.

A two-way analysis of variance (low-high Openness $\mathbf{x}$ lowhigh Dominance) was performed for each of these two measures. For the measure of openness, a significant main effect between the low Openness $(\underline{M}=2.31)$ and the high openness $(\underline{M}=4.60)$ groups, $\underline{F}(1,36)=18.56, p<.05$, was found. For the measure of dominance, a significant main effect was found between the low Dominance $(\underline{M}=2.90)$ and the high Dominance $(\underline{M}=6.42)$ groups, $\underline{F}(1,36)=71.63, p<.05$. The openness groups also were significantly different (low $=3.84$, high=5.35) on the dominance measure, $\underline{F}(1,36)=11.46, p<.05$.

These results indicate that the tapes were perceived as intended. Subjects perceived the salesperson in terms of Openness and Dominance as manipulated. 


\section{Procedure}

Subjects were randomly assigned to conditions. In addition, within each condition, time of day and day of week were randomized. Groups of five and six subjects were run at a time.

Subjects were first asked to complete a self-report of Norton's communicator style measure after which they were shown a videotape of the sales presentation (See Appendix B for instructions and response questionnaire).

After viewing the tape, subjects were asked to complete a questionnaire consisting of a series of Likert-type items. The questionnaire consisted of 42 items containing communicator style measures, items measuring attraction to the communicator, perceptions of the product being sold in the tape as well as customer's and respondents' judgments of the probability of purchasing from the communicator. Several of the questions were examining the same concept and we identified groups of questions that were a priori related. As a result, a composite score was calculated from these questions by combining the individual question responses and finding a mean value. Six composite scores were identified: (1) general attitude toward salespeople (GSAT), perceptions of the product being sold in the tape (PROD), interaction between the salesperson and customer in the tape (INTER), (4) general buying behavior of the respondent (BUYB), (5) probability of purchase of the product in the tape (BUYPRO), and (6) perceptions of the salesperson being 
depicted in the tape (PERSON). See Table 1 for the individual items and the mean responses.

\section{Insert Table 1 about here}

\section{Results}

Separate two-way ANOVAS for each measure were run with Openness and Dominance as independent variables for the measures of openness, dominance, and the six composite measures. All measures ranged from 1 (strongly disagree) to 7 (strongly agree).

The analyses for the measures of general attitude toward salespeople attitude (GSAT) and observer buying behavior (BUYB) did not yield any significant effects. Both of these measure an overall attitude and general behavioral intentions totally unrelated to the specific situation depicted on the tape.

For the open construct, there were significant main effects for the Dominant condition. Subjects in the high Dominant group saw the salesperson as more open $(\underline{\underline{M}}=4.74)$ than those in the low Dominant group $(\underline{\underline{M}}=4.02) \quad \underline{F}(1,75)=$ $5.105, p<.05$. The proportion of variation explained by the manipulation of Dominance as measured by omega squared $\left(w^{2}\right)$ for the open variable was equal to .049 .

For the dominant measure, both main effects as well as the interaction were significant. Subjects in the high open condition viewed the salesperson as significantly more 
dominant ( $\underline{M}=5.56)$ than those in the low open condition $(\underline{M}=4.16) \underline{\underline{F}}(1,75)=12.972, p<.01, w^{2}=.1011$. Likewise, subjects in the high Dominant condition viewed the salesperson as more dominant $(\underline{M}=5.77)$ than those in the low Dominant condition $(\underline{M}=4.02) \underline{F}(1,75)=19.861, \underline{p}<.001, w^{2}=$ .1593. In terms of the interaction, respondents in the low Dominant condition rated the salesperson as more dominant in the high open than in the low open condition; whereas in the high Dominant condition, subjects' distinctions between low Open and high Open were not as clear. $\underline{E}(1,75)=9.893, p<.01$, $w^{2}=.0751$. See Table 2 for the individual cell means.

Insert Table 2 about here

The PROD factor referred to the respondents' perceptions of the product being sold in the tape. There was a significant main effect for Dominance. Subjects rated the product in the tape significantly higher in the high Dominant condition $(\underline{M}=4.82)$ than in the low Dominant condition $(\underline{M}=$ 4.24) $\underline{F}(1,74)=6.705, p<.05, w^{2}=.0644$. There was also a significant interaction between openness and Dominance. In the low Dominant condition, subjects who saw the high open tape rated the product more favorably than did subjects who saw the low open tape. The opposite was the case for the high Dominant condition however. Here, subjects in the low Open condition rated the product higher than subjects in the high open condition $\underline{F}(1,74)=6.036, p<.05, w^{2}=.0568$. See 
Table 3 for the individual cells for the interaction.

Insert Table 3 about here

The INTER variable which represented the interaction between the customer and the salesperson, produced a significant main effect for openness where subjects in the low open condition rated the salesperson/customer interaction higher $(\underline{M}=4.41)$ than those in the high open condition $(\underline{M}=$ 3.56) $\underline{E}(1,74)=19.781, \mathrm{p}<.001, \mathrm{w}^{2}=.1927$

The BUYPRO factor referred to respondents' probability of hypothetically buying the product being sold in the tape. Both main effects showed significance. In the open conditions, the low open communicator produced more favorable responses $(\underline{M}=3.79)$ than did the high open communicator $(\underline{M}=$ 2.86) $\underline{F}(1,74)=9.766, p<.01$. However, in the Dominant condition, high Dominance elicited more favorable responses in terms of probability of buying the product $(\underline{M}=3.62)$ than did the low Dominance $(\underline{M}=3.00) \underline{F}(1,74)=4.388, p<.05, w^{2}$ $=.066$.

Finally, the PERSON variable, referring to the specific salesperson in the tape, showed a significant main effect for dominance only. Again, the high dominant salesperson was rated more favorably $(\underline{M}=4.17)$ than was the low dominant salesperson $(\underline{\underline{M}}=3.72) \underline{F}(1,75)=6.765, p<.05$. 


\section{Discussion}

It is interesting to note that there were no significant differences among conditions for the GSAT, general attitude toward salespeople and the BUYB, observer buying behavior composite measures. These findings were consistent with expectations of no differences among the sample groups. One would not expect to see significant differences among conditions since these two measures are examining factors that were extraneous to the manipulations.

The four composite measures which showed significant effects were PROD, INTER, BUYPRO and PERSON. All four of these factors examine specific aspects or perceptions of what was taking place on the tape.

For the PROD variable, it seems that subjects see a product in a more positive way when a salesperson displays a certain degree of dominance. Perhaps the dominant salesperson, in his or her appeal to customers, is more persuasive and convincing about the positive attributes of the product.

The interaction between the customer and salesperson in the tape, the INTER variable, was seen in a more positive way when the salesperson displayed less openness. A salesperson who is very open may not allow much opportunity for a two-way interaction to occur, i.e. the conversation may be one-sided. In addition, since the open salesperson talks about him/herself, and not much about the product or its attributes, the interaction may appear to be an inequitable 
one. Usually, in a sales interaction, the customer's goal is to seek information about the product. This is especially true for an innovative product. High openness on the part of the salesperson may preclude the customer from obtaining the information $s /$ he wants.

For the BUYPRO variable which referred to the likelihood or probability of the respondent buying the product that was being sold in the tape, main effects for both Dominance and Openness were found to be significant. The more open the salesperson was, the less likely respondents were to indicate that they would buy the product. Conversely, for Dominance, subjects in the High Dominant condition indicated that they would be more likely to buy the product than did subjects in the low Dominant condition. These results parallel those for the other composite measures. Again, when a salesperson demonstrates high openness, his/her side of the conversation focuses on him or herself and therefore, the observer or customer may feel that $s /$ he doesn't have enough information about the product to make a buying decision. The high Dominant salesperson, in monopolizing the conversation, may have disseminated enough information about the product for the observer/customer to make a buying decision. This is indicated by the greater likelihood of buying the product by those in the high Dominant condition.

This notion that it is the Dominance characteristic that is enhancing the probability of purchase is further supported by the results of the ANOVA for the PERSON composite where 
main effects were significant for Dominance: The high Dominant salesperson was rated more positively than the low Dominant salesperson.

Respondents, in general, rated the high Dominant/low Open and low Dominant/high open conditions higher than the high Dominant/high open or low Dominant/low open conditions. A certain amount of dominance on the part of a salesperson seems to be desired as indicated by observers of a sales interaction. However, it seems that if this is the case, customers do not like a salesperson who is also very open as manipulated on the tape. It appears that respondents were mistaking Dominance for Openness. Openness may have been confused with dominance since openness involves much talking about oneself. Thus, customers may perceive the high Dominant/high open salesperson as overly dominant therefore accounting for the lower ratings on many questions for this condition. This finding is also consistent with the findings of the Hayes and Meltzer (1972) study described earlier. Apparently, consumers prefer to do business with and generally perceive in a more positive way, salespeople who (1) do not talk much about themselves and who are not conversational, gregarious or frank. and (2) are somewhat confident, enthusiastic and forceful.

Perhaps with limited free time available to them, shoppers prefer not to waste time listening to conversation which is unrelated to the task at hand. This notion may be further influenced by the fact that the product being sold in 
the tape was an innovative one requiring much information dissemination. The customer, therefore, may not be tolerant of conversation which is not directly related to the product. Furthermore, it seems that not only are people's perceptions of salespeople affected by the communicator style of the salesperson, but so are people's perceptions of the product being sold.

Pearson product moment correlation coefficients were calculated to assess the relationships among the composite measures (see table 4). The four correlations which were

Insert Table 4 about here

significant were PROD $\times$ BUYPRO $(r=.43)$, INTER $\times$ BUYPRO $(r=.44)$, INTER $\times$ PERSON $(r=.48)$ and PERSON $\times$ BUYPRO $(r=.40)$. Again, this shows that the factors that are relating are only those which are specific to the interaction on the tape. In thinking about the PERSON $\mathrm{x}$ INTER correlation it may be difficult to separate out perceptions about one person in the tape (i.e. salesperson) from perceptions about the interaction that is taking place between the customer and salesperson. The BUYPRO $\mathrm{x}$ INTER correlation also makes intuitive sense. It seems logical that the observer would or would not be willing to buy the product being sold in the tape based upon his/her perceptions of the interaction in a positive or negative way. The interaction is viewed more negatively when there is a greater degree of openness on the 
part of the salesperson. Perhaps a talkative salesperson precludes a customer from becoming involved in the interaction. It seems that a better approach might be for a salesperson to invite conversation from the customer and to get the customer involved. An individual who is a "take charge" type person and who involves the customer in the sales interaction as much as possible without being overly talkative, may possess the ideal communicator style for maximum sales effectiveness. It is important to note again that this particular study utilized observers and before any definitive conclusions can be drawn, one may want to obtain the same type of information from those who are part of the sales interaction (e.g. actual customers). Nevertheless, the findings of this study may have important implications for sales managers in terms of designing sales training programs.

\section{Future research}

Since communication style in a marketing context remains a new field of investigation, there are several directions in which future research can move.

Norton style dimensions other than Dominance and Openness should be examined to determine their role in the sales situation. For example, the Dramatic and Animated style dimensions seem appropriate to a sales situation in terms of possibly affecting sales outcome: Dramatizing influences popularity, status, self-esteem and attraction (Norton 1978). These are all qualities that appear to be directly related to sales effectiveness. The Animated communicator provides 
frequent and sustained eye contact, and uses many facial expressions and gestures often (Norton 1978). It would be interesting to examine how these qualities are perceived by an observer of a sales interaction. In addition, the Friendly communicator confirms, strokes and positively recognizes the other. Norton (1978) states that this style dimension is a solid predictor of attraction, leadership, socialability and social status.

The product in the present study was an innovative one. When shopping for a product that they've had no experience with, such as the one being sold in the tapes, customers seek out as much information as possible. Therefore, respondents tended to see the Dominant salesperson who, in monopolizing the conversation also provided information about the product, in a positive way. Perhaps if the product were an imitative one or an adaptive replacement where minimal product information is needed, the customer would be tolerant of general conversation.

Finally, a field study that utilizes the Norton style measure would aid in increasing the external validity of this study, as would utilizing as subjects those actually involved in the sales interaction, i.e. customers. 
Table 1

Composite Measures and Questionnaire Items

\begin{tabular}{|c|c|c|}
\hline \multicolumn{2}{|c|}{ Composite measures } & Questionnaire item \\
\hline$\underline{\underline{M}}$ & $\underline{\text { SD }}$ & $\underline{\mathrm{M}}$, \\
\hline GSAT & & $\begin{array}{l}\text { - Sales people are basically } \\
\text { deceptive.* }\end{array}$ \\
\hline 4.440 & .872 & $\begin{array}{l}4.65, \quad 1.433 \\
\text { - Salespeople are usualiy helpful. } \\
5.49, \quad .860 \\
\text { - I like a salesperson who tells me a } \\
\text { lot about a product. } \\
4.33, \quad 1.838 \\
\text { - I like a salesperson who engages in } \\
\text { general conversation. } \\
4.28, \quad 1.783 \\
\text { - I like when a salesperson takes a } \\
\text { personal interest in me. } \\
5.12, \quad 1.453 \\
\text { - I prefer not to have a salesperson } \\
\text { help me in evaluating a product.* } \\
3.92, \quad 1.711\end{array}$ \\
\hline PROD & & $\begin{array}{l}\text { - This product at this price is a } \\
\text { bargain. }\end{array}$ \\
\hline 4.535 & 1.054 & $\begin{array}{l}4.28, \quad 1.577 \\
\text { - This product represents a true } \\
\text { innovation for the music industry. } \\
5.06,1.651 \\
\text { - Many people will want to buy this } \\
\text { product. } 4.65, \quad 1.494 \\
\text { - This product is especially } \\
\text { appropriate for college students. } \\
4.15, \quad 1.610\end{array}$ \\
\hline INTER & & $\begin{array}{l}\text { - This salesperson tended to } \\
\text { monopolize the conversation.* }\end{array}$ \\
\hline 3.958, & .939 & $\begin{array}{l}4.95, \quad 1.999 \\
\text { - The salesperson was animated. } \\
4.86,1.700 \\
\text { - The interaction between the } \\
\text { salesperson and the customer in the } \\
\text { tape was very friendly. } \\
3.95, \quad 1.724 \\
\text { - The interaction between the } \\
\text { salesperson and the customer was } \\
\text { very strained.* } \\
4.29,\end{array}$ \\
\hline
\end{tabular}


Table 1 (continued)

BUYB

$3.785,1.015$

BUYPRO

$3.30,1.428$

PERSON

$3.943, .801$
- The interaction between the salesperson and the customer in the tape was very relaxed.

$$
3.32, \quad 1.743
$$

- The salesperson in the tape was direct in answering the customer's questions.

$$
4.32, \quad 1.684
$$

- The customer in the tape was interested in what the salesperson had to say.

$$
4.75, \quad 1.498
$$

- I always shop for the lowest price product available.

$$
3.39, \quad 1.628
$$

- When purchasing high ticket items, I usually value a salesperson's opinion.

$$
4.177,1.639
$$

- The likelihood that the customer in the tape bought

the product is:

$$
4.04, \quad 1.864
$$

- Once this product is introduced in stores I will probably purchase one. $3.392, \quad 1.815$

- The likelihood that I would have bought this product from this salesperson is:

$$
2.47, \quad 1.647
$$

- This salesperson was honest.

$$
4.03,1.544
$$

- This salesperson was an effective communicator.

$$
3.44, \quad 1.730
$$

- This salesperson was nervous.*

$$
3.18,1.831
$$

- The salesperson is usually the type that I like to do business with.

$$
2.41, \quad 1.613
$$

- The salesperson was relaxed.

$$
\text { 4.15, } 1.902
$$

- This salesperson was competent.

$$
4.41,1.565
$$

- The salesperson was dramatic.

$$
4.04,1.843
$$

- The salesperson was intelligent.

$$
4.04, \quad 1.265
$$

- The salesperson in the tape left me with a positive impression.

$$
2.77, \quad 1.569
$$

- The salesperson was precise.

$$
4.20, \quad 1.418
$$


Table 1 (continued)

- The salesperson was friendly.

$$
4.32, \quad 1.614
$$

- The salesperson was open.

$$
4.38, \quad 1.444
$$

- The salesperson was contentious.*

$$
4.20, \quad .897
$$

- The salesperson in the tape was approachable.

$$
\text { 4.15, } 1.747
$$

- The salesperson in the tape was dominant.

$$
4.89, \quad 2.154
$$

- The salesperson in the tape was impression-leaving.

$$
4.46, \quad 1.738
$$

- The salesperson in the tape was attentive.

$$
4.11, \quad 1.585
$$

Note. Scales ranged from (7) strongly agree to (1) strongly disagree.

* Scores on these items were reversed because of negative wording. 
Table 2

Cell Means for the Measure of Dominance in the Dominant $x$ openness Interaction

\begin{tabular}{llr}
\hline & \multicolumn{2}{c}{ Dominant } \\
\cline { 3 - 3 } Open & low & high \\
\hline low & 2.63 & 5.68 \\
high & 5.29 & 5.85 \\
\hline
\end{tabular}


Table 3

Cell Means for the composite of PROD in the Dominant $x$ openness Interaction

Dominant

Open

low high

low

4.07

5. 22

high

4.39

4.45 
Table 4

Pearson Product Moment Correlation Coefficients for composite Measures

\begin{tabular}{|c|c|c|c|c|c|}
\hline Composite & PROD & INTER & BUYB & BUYPRO & PERSON \\
\hline GSAT & .1193 & -.0337 & .1903 & -.0965 & -.0643 \\
\hline PROD & & -.0068 & -.1127 & $.4315 * *$ & -.0325 \\
\hline INTER & & & -.0076 & $.4444 * *$ & $.4788 * *$ \\
\hline BUYB & & & & -.1850 & -.0732 \\
\hline BUYPRO & & & & & $.4024 * *$ \\
\hline
\end{tabular}

$* \underline{p}<.01 . \quad * * \underline{p}<.001$. 


\section{REFERENCES}

Bass, B. M. (1960). Ieadership, Psychology, and organizational Behavior. New York: Harper Bros.

Bass, B. M. (1967). Social behavior and the orientation inventory: A review. Psychological Bulletin, 68, 260-92.

Bednar, D. A. (1982). Relationships between communicator style and managerial performance in complex organizations: a field study. Journal of Business Communication, 19, 5175 .

Blake, R. R., \& Mouton, J. S. (1980). The grid for sales excellence (2nd ed.). New York: McGraw-Hill.

Brock, T. C. (1965). Communicator-recipient similarity and decision change. Journal of Personality and Social Psychology, 1, 650-654.

Bushard, B. I. (1959). Methodology of the study. In K. I. Artis (ed), The symptom as communication in Schizophrenia. New York: Grune \& Stratton.

Capon, N., Holbrook, M. B., \& Hulbert, J. M. (1977). Selling process and buyer behavior: Theoretical implications of recent research. In A. G. Woodside, J. N. Sheth \& P. D. Bennett (eds), Consumer and Industrial Buying Behavior. New York: Elsevier North Holland, Inc.

Evans, F. B. (1963). Selling as a dyadic relationship - a new approach. American behavioral scientist, $6,76-79$.

Hayes, D., \& Meltzer, L. (1972). Interpersonal judgments based on talkativeness: fact or artifact. sociometry, 35 , 338-561.

Hulbert, James \& Capon, Noel (1972). Interpersonal communication in marketing: an overview. Journal of Marketing Research, 9 , 27-34.

Mathews, H. I., Wilson, D. T., \& Monoky, J. F. (1972). Bargaining behavior in a buyer-seller dyad. Journal of Marketing Research, 9, 103-05.

Mortensen, D. A. (1972) . Communication: The Study of Human Interaction. New York: McGraw-Hill Book Company.

Norton, R. (1977). Teacher effectiveness as a function of communicator style. In B. D. Ruben (ed.), communication Yearbook I. New Brunswick: Transaction Books.

Norton, R. (1978). Foundation of a communicator style construct. Human Communication Research, 4, 99-112. 
Norton, R., \& Miller, L. (1975). Dyadic perception of communication style. Communication Research, $\underline{2}$, 50-67.

Norton, R. \& \& Pettegrew, L. S. (1977). Communicator style as an effect determinant of attraction. Communication Research, 4, 257-82.

Norton, R., Syphner, H., Clarke, C., \& Brady. (1977). Dimensions of a dramatic communicator style. Paper presented at the annual meeting of the speech communication Association, Washington, DC.

Norton, R., Baker, N., Bednar, D., Sayler, R., \& McGough, T. (1978). Impressions of interpersonal dramatic style. Paper presented at the annual meeting of the speech Communication Association, Minneapolis, MI.

Norton, R. \& Bednar, D. A., (1979). Ideal communicator style for the interviewee. Paper presented at the annual meeting of the International Communication Association, Philadelphia, PA.

Norton, R., \& Montgomery, B. (1979). An integration of style, content, and target in defining and measuring openness. Paper presented at the annual meeting of the International Communication Association, Philadelphia, PA.

Norton, R., \& Nussbaum, J. (1980). Dramatic behaviors of the effective teacher. In Nimmo, D. (ed.) Communication

Yearbook. 4 , New Brunswick: Transaction Books.

Norton, R. \& Miller, L. D. (1975). Dyadic perception of communication style. Communication Research, 2, 50-67.

Norton, R., Pettegrew, L. S., \& Land, S. (1975). Communicator style correlates of attraction. Paper presented to the International Communication Convention, Chicago.

Norton, R., \& Pettegrew, L. S. (1979). Attentiveness as a style of communication: A structural analysis.

Communication Monographs. 46, 13-26.

Norton, R., \& Robinson, D. Communicator style in career decisions. Paper presented at the annual meeting of the Speech Communication Association. New York.

Pace, W. R. (1962). Oral communication and sales effectiveness. Journal of Applied Psychology, 44, 487-8.

Padgett, V. R., \& Wolosin, R. J. (1980). Cognitive similarity in dyadic communication. Journal of Personality and Social Psychology. 39, 654-9. 
Sheth, J. M. (1976). Buyer-seller interaction: A conceptual framework. Proceedings of the Association for Consumer Research. Cincinnati, OH: Association for Consumer Research, 382-6.

Staley, C. C., \& Cohen, J. L. (1988). Communicator style and social style: similarities and differences between the sexes. Communication Quarterly. In press.

Williams, K. C. \& Spiro, R. L. (1985). Communication style in the salesperson-customer dyad. Journal of Marketing Research. 22, 434-42.

Woodside, A. G. \& Davenport, W. J., (1974). The effect of salesmen similarity and expertise on consumer purchasing behavior. Journal of Marketing Research. 11, 198-202. 
Appendix A

\section{Scripts}


High Dominant - High open Communicator style

(type 1)

Tendency to come on strong. Taking charge of thing. Speaks very frequently. Self disclosing. Expresses feelings and emotions. Other reople jenerally kno: the emotional state. 
S: (observing customer looking at stereo unit) Good morning, is this the first time that you're seeing one of these units?

C: yes, I've...

S: Nell you've come to the right place, we're the pioneers in the area. Did you know that we began carrying these before they were even advertised to the seneral public?

C: No, I didn't realize that

S: Furthermore, I'm the person that everyone can thak for it I just love to listen to good music and so I'm constantly reading up on bew innovations in the industry. As a matter of fact my wife (husband) sometimes to so many trade masazines - I spend nearly all night reading them. Hell if this is the first time vou're hearing about the , Iet he tell you all you want to know.

a: thy is everyone makin such $a$ bij geal abou them? that is supposec to be so trenencious?

S: iverythin is tremendous about the - The unit is available in both a home and portable nociel. There are various noclules available in different music varieties. Hocules are zvailable for hard rock, soft rock, jazz, classical and country and western. That tyre of music do you prefer to listen to?

C:Usually jazz.

3: (rather exciter) You have excellent taste: izaz is my favorite also. A a natter of fact that's practically all I listen to. I was in a jazz band for several years - we won many awards. I still dream about playing with the group but I had to leave when they began traveling. I vas still in school then and, although it was 
a diffichlt decision, I know that I needed to neles my conitinent to finishing school. inyway, once the module is hooked in, you simoly program in the songs that you want by punching in a 6-digit code. The unit has a capacity to store up to 500 songs at one time. ilere, put these earphones on ( $S$ hands $C$ a set of earphones,) I guess you know that this is the best way to evaluate the unit listen for yourself. I'm going to punch in my favorite song. Iisten to the clarity of the instruments, especially the sax, that's what I used to play.

(after a few ninutes $C$ taires the earphones off)

S: How do you like it? Izn't that the most supery-sourcing :uede rev've ever hear??

C: It's good (a somerhat negative irficectior. jy vrice)

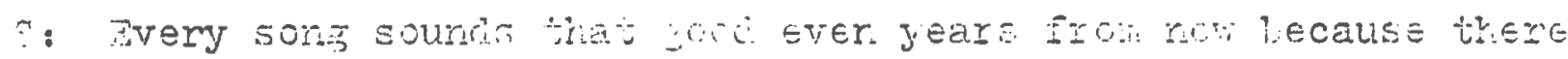

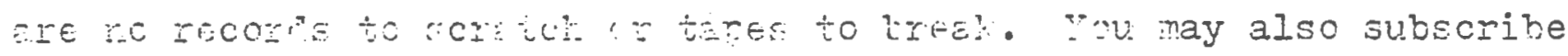
to the update semice whic consists of a monthly listing of new song releases for your nocule along rith their coce numbers. Last week when I received newsletter. I was up unil 3:00 am. just punching in coces and listening to new relezses.

$c:$ Ho: much roes the unit cost?

3: Are you reaiy for this? Just 199.95 and we are offering an introductory special. For this price you will receive one free module pius six months subscription to the newsititer. I could take your order today.

C: I vant a litile tine $\div$ thini it over.

a y job is to helo rou thint it over - are there any adeitional questions I can answer for you? 
s: :o, but mill you be here tomorro:

S: only during the day, E've-zot tiekets to a jaz concert at nijht. Afriend ${ }^{\prime}$ haven't seen for four-years-is coming in from out of tom, I've had-these tickets for two months, I...

C: I'Il make a decision by tomorrow.

3: Do you have a charge account ith us?

C:

I: Fiere is an application form. If rou'll complete it now, I can have it aporoved by tonorrow. All you need to jo is to call and I'II have your unit celiverec.

(They shake han an an canera. Taries out) 
High Doninant - Iow open Commicator Style

(type 2)

Tencency to come on strous. In-es charge of Gings. Dpeaks very frequently. Does not disclose nuch about self when with others. Does not express feelinxs and emotion. 


\section{YITH DOTINANT - TON OPEN}

J - BAIIEFERSOT

- $-10 \mathrm{ros}$

I: (Observing customer looking at stereo unit) good norning, is this the first time that you're seeing one of these units?

C: yes, I've...

S: Tell you've come to the right place, we're pioneers in the area. Did you know that we bejan carrying these before they were even arvertised to the jeneral public?

C: No, I cifint realize that. Thy is everyone making such a bis deal about them? "hat is supposed to be so tremendous?

S: Iverything is tremencous about the - The unit is available in both a home and portable model. There are various modules available in jiîferent music varieties. Nodules are available for hard rock, soft rock, jazz, classical and country \& western. inat troe of uuic co you prefer to iisten to?

c: UsualIy Jazz.

5: You have excelient taste. inyway, once the module is hooked in, rou singy prosram in the songs that you nant by punching in a órijit coce. ihe unit has a capacity to store ue to 500 songs at one time.

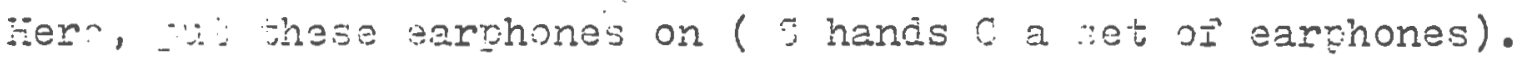
I zuess you know that this is the best way to evaiuate the unit listen for yourseif. I'm going to punch in a sonj that's everyones favorite. Iisten to the clarity of the instruments.

(after a fen ninutes $C$ tares the earphones off) 
s: How do you like it? Isn't that the most superb-soundin? music you've ever heard?

C: It's good ( a somewhat negative inflection in voice)

S: Every song sounds that good even years from now because there are no records to scratch or tapes to break. You may also subscribe to the upcate service which consists of a monthly listing of new song releases for your module along with their coie numbers. I last customer tol. ne he was up until $3: 00 \mathrm{~mm}$ just punchiaj an cos and listening to new releases when he received his rirst uecate.

C: How much cioes the unit cost?

3: ise you reacy ion this? Just 9199.95 and we are offering an introductory special. For this price you will receive one free norile plus siz nonths subscription to the newsletter. I could talie your orer today.

C: I.want a littie time to thing it over.

3: $\mathrm{y}$ job is to helo you think it over - are there any additional guestions I can ans"ier for you?

c: iro, but will rou be here tomoreom?

: nly vring the day. I con't tant you to niss the offer which is goos only through tonorrow. I want to to receive the best service so be sure to jet uack to ne before $5: 00$.

E: I'II nake a Eacision oy tomormo 
$\because$ To vou have a charge account with us?

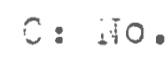

I: تiere is an application form. If you'll complete it now, I can have it approved by tomorrow. All you need to do is to call and I'Il have your unit delivered.

(They shake hancs anc. camera fajes out) 


\section{Iori Doninant - \#ish ipen Communicator Style (type $:$ )}

Dos: not come on strons. Is rather submissive when mith others. yesirs only uhen necesum. Loes not disclose much about self when uth others. Joes not express feeljngs an enotion. 
s: (Observing customer looking at stereo unit) Gooci norning.

C: yood inorning (waits for $s$ to respond, $s$ does not responc)

- $a$ this the neiv stereo unit that can be prozrammed?

$\because$ Yes, it is, have you seen it before?

c: No, I haven't but it be interested in knoming nore about it.

; I can certainly tell you that, I just bought one for myself. The___ is araijaile in both a hone and a portable model. It joerates on a morule that is progranmed for a particular music type. That type of music do you listen to?

C: Jazz

S: You have exnollent tarte! Jazz is my favonite also. As a natuer of fact that'o ractically all I li ten to. I was in $a$ iazo bind For sevoraz years.

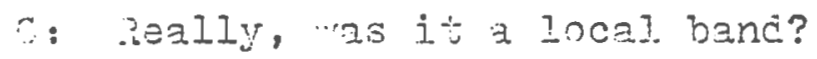

S: Yer, we mon nany ewaris. I still cream about playing with the froup but I hac to leave when they began traveing. I was still in school then and, although it $: a s$ a jeficult ecision, I know that I neesed to mak ny comittment to Iinishing school. Anyway, once the morule is hooked in, you simply progra? in the songs that you want by punching in a b-cijit core. The unit has a capacity to store un to 500 soins at one time.

c: could I listen to it?

: Sure, it's the best :ray to evaluate the unit. That's what sold me on it. inene, put these earphones on (i hans a set of earphones). I'n going to punch in my favorite song. Listen to the clarity of the instruments, especially the sax, that's what I usec to play. 
I: Are there any adritional questions I can answer for you?

G: $\quad$ o, but i'lz aka a decision by tomorrow, vill you be here Hen?

I: only curing the day. (I've got tickets to a jazz concert at night. $A$ friend wo I haven't seen for four years is coming in from out of town, I've had these tickets for two months. If you decide thet y... iant the unit, just call and I can arrange to have it dielivered whenever you want.)

- (They shere hancs an canera paces out) 
Low Dominant - Low Open Communicator Style (type 4)

Does not come on strong. Is rather submissive when with others. speaks only when necessary. Does not disclose much about self when with others. Does not express feelings and emotion. 
S: (observing customer lookins at stereo luit). Jood norning.

$C$ : Good morning (waits for $S$ to respond, $S$ does not respond)

Is this the new stereo unit; that can be programmed.

S: Yes, it is, have you seen it before?

C: No, I haven't but I'd be interested in know more about it.

S: Certainly, the ___ is available in both a home and a portable model. It operates on a module that is programmed for a particular music type.

C: That music varieties are available

S: Hard rock, soft rock, jazz, classical and country \& western.

C: Fow does the nodule work?

-: ince the module is hooked in, you can prozram in the songs that you want by punching in a ó-cigit code.

E: Yo: many sonse can the store at one time.

S: It has a capacity to store up to 500 songs at one tome.

C: Coulc I listen to it?

$\therefore$ : Sure, it's the best way to evaluate the unit - what type of music to you prefer?

\section{C: Jazz}

(after a fe* minutea (j takes the earphones off') 
How do rou itre it?

c: It sounds good.

S: You'll find that every song sounds that good even years from no: because there are no records to scratch or tapes to break.

C: What about new songs that are released, how will I find out their program codes?

S: You may subscribe to the uodate service. This consists of a monthly listing of new song releases for your module along with their code numbers.

C: How much does the unit cost?

S: The price is 190.95 . Included in that price is one module and six months subscription to the newsletter.

: Fo: soon mill you be taking orders?

$\because$ I coule tare orcers tolay.

C: I want a little time to thing it over.

s: rentainly, are thare any adeitional guestions i can answer for you?

c: $\because 0$, but

s: yes, but only curing the say.

C: I'II get in touch ith you then, shoule I cai finst.

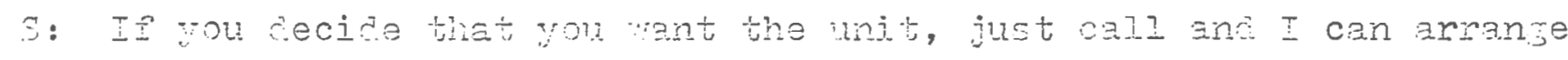
to have it deiryerec whenever you want. 
Appendix B

Instructions and Response Questionnaire 
You have impressions of yourself as a communicator. Those impressions include your sense of the way you communicate. This measure focuses on your sensitivity to the way you communicate or what is called your communicator style.

The questions are not designed to look at what is communicated; rather, they explore the way you communicate.

Because there is no such thing as a "correct" style of communication, none of the following items have right or wrong answers.

Some questions will be difficult to answer because you honestly do not know. For these questions, however, please try to determine which way you are leaning and answer in the appropriate direction.

The following scale is used for each item:

YES! = strong agreement with the statement

yes = agreement with the statement

? = neither agreement or disagreement with the statement

no = disagreement . with the statement

No! = strong disagreement with the statement

For example, if you agree with the following statement, "I dislike the coldness of winter," then you would circle the "yes" as indicated:

No! no ? Yes YES!

Some of the items will be similarly stated. But each item has a slightly different orientation. Try to answer each question as though it were the only question being asked.

Finally, answer each item as it relates to a general face-to-face communication situation...namely, the type of communicator you are most often. 
My age 18. My major 18

I an H/P (cIrcle one). I am a: Fr so Jr Sr (clrcle one)

1. I an comfortable with all varletles of people.
no yes!

2. I laugh easily; nol yes yes!

3. I readily expres admiration for others. Nol no ? yes YeS!

4. What I say uarady leaves an impression on people. No! no ? yes YES ?

5. I leave people with an impression of myself which they definitely tend to remember. NO! no? ? yes YES!

6. To be friendly. I habitually acknowledge verbally other's contributions. No! no ? yes Yes!

7. I an a very good communicator. No! no ? yes YES !

B. I have some nervous mannerisms in my speech.

9. I am a very relaxed communicator. Nol no ? yes YES!

10. When I disagree with somebody, I am very quick to challenge them. No! no ? yes YES!

11. I can always repeat back to a person exactly what was meant. No! no ? : yes YES!

12. The sound on my volce is very easy to recognize. Nol no ? yes YES

13. I am a very precise communicator. Nol no ? yes YES

14. I leave a definite Impression on people. No! no ? yes YES!

15. The rhythm or flow of my speech is sometimes affected by my nervousness. Nol no $?$ yes YES!

16. Under pressure I come acroas as a relaxed speaker. Nol no ? Yes Yes!

17. My eyes reflect exactly what I an feeling when I
communicate. nol no ? yes YESI

18. I dramatize a lot. NO! no ? Yee YES!

19. I always find it yery easy to communicate on a one-to-one baels with strangers;

20. Usually, I deliberately react in such a way that people know that I an listening to them. Nol no ? yes YES

21. Usually I do not tell people wuch about myself until I get to know then well. Nol no $?$ yes YES

22. Reqularly I tell jokes, anecdotes and storles when I communicate. Nol no $?$ yes YES

23. I tend to constantly gesture when I communicate. Not no ? yee YES

24. I am an extremely open comunicator. No! no ? yes YES 
25. I an vocally a loud communtcator.

nol no ? yes yes

26. In a sal1 group of strangers I an a yery good communicator. HOI no $?$ yes Yes

27. In argumente I insiet upon very precise definitions.

Nol no ? yos yes

28. In most social situations I generally speak very frequently. Hol no ? yes Yes

29. I eind 1t extremely easy to maintain a conversation with a nember of the opposite sex yhon I have tuat mat.
noi no yes

30. I 11ke to be atrletly accurate when I communicate. Nol no ? yes Yes

31. Because I have a loud volce I can easily break Into a convarsation. Nol no ? yes YES

32. Often I physlcally and vocally act out what I want to conminicate. HOl no ? Yes YES

33. I have an assert1ve volce. YES
Hol no ?es 34. I readily reveal personal things about myself.

35. I an dominant in soclal situations. NO! no ? Yes YES

36. I an very argumentative. No1 no 7 yes YES

37. Once I get wound up in a heated discussion, I have a hard

t1we stopping mysele. Nol no ? Yes Yes

38. I am always an extremely friendly communicator. Nol no ? yes YES

39. I really like to 11 sten yery carefully to people. No! no ? yes Yes

10. very often I inalst that other people document or present some kind of prook for what they are arguing. Nol no? $?$ yes YES

41. I try to take charge of things when I an with people. Nol no?

42. It bothers me to drop an argument that is not resolved. No! no?

43. In most soclal gituatlons I tend to come on strong.
MOI

14. I aim vary expressive nonverbally in social situations. Nol no ? yes yes

45. The way I say something usually leaves an impression on people.

Hol no ? yea Yes

46. Whenever I comunicate, I tend to be very encouraging to people.

MO! no ? yes YES

47. I ectivaly use lot of facial expressions when I comunicate. Nol no $?$ Yes YES

18. I yery frequently verbally exaggerate to emphasize a point.

49. I an an extrenely attentive communicator.

50. As a rule, I openly express my feellinga and emotions. NO! no ? yes YEs

out of a randor group of $1 \times$ people, including myselr, I would probably have a better communicator style than (clrcle one cholee):

of the of them of ${ }^{3}$ them of them of then


PLEASE STOP HERE! YOU WILL BE SHOWN A VIDEOTAPE BEFORE PROCEEDING 
You have just been shown a tape depicting an interaction between a salesperson and a customer. In what follows, we are trying to obtain your true reactions to what you have just seen. Please read each statement carefully before checking the category that best describes your reactions. 


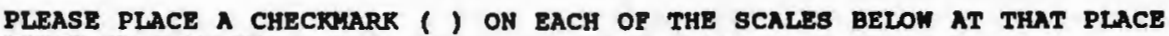
WHICH BEST REFTBCTS YOUR REACTIONS IN GENERAL.

1. Salespeople are bastcally deceptiver

STROTCLY ' AGREE AGREE AGREE NOR DISAGREE DISAGREE DISAGREE DISAGREE

2. salespeople are usually helpful:

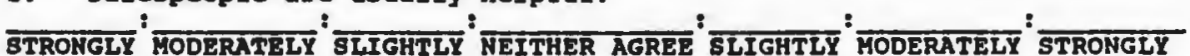
AGREE AGREE AGRE NOR DISAGRE DISAGREE DISAGREE DISAGREE

3. I always shop for the lowest prlce product avallable:

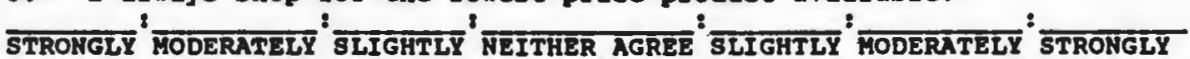
AGREE AGREE AGREE NOR DISAGREE DISAGREE DISAGREE DISAGREE

4. When purchasing high ticket ltens, I usually value a salesperson's oplnion STRONGLY
DISAGRE
DISAGRTEL
DISTEE

5. I I1ke a salesperson who tells me a lot about a product even If I don't ask for the information.

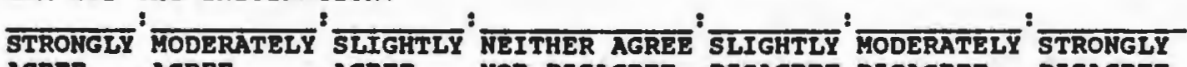
AGREE AGREE AGREE NOR DISAGREE DISAGREE DISAGREE DISAGREE

6. I I1ke a salesperson who engages in general conversation:

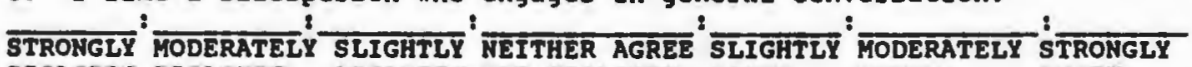
DISAGRE DISAGREE DISAGREE NOR DISAGREB AGREE AGREE AGREE

7. Th1s product at this price $1 \mathrm{~s}$ a bargain:

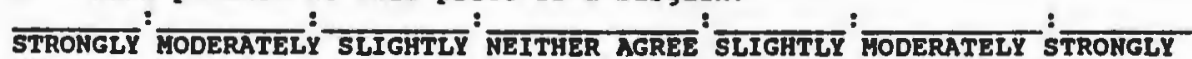
DISAGREE DISAGREE DISAGREE NOR DISAGREE AGREE AGREE AGREE

8. This salesperson tended to monopolize the conversation:

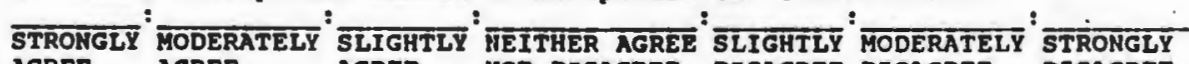
AGREE AGREE AGREE NOR DISAGREE DISAGREE DISAGREE DISAGREE

9. The salesperson was animated:

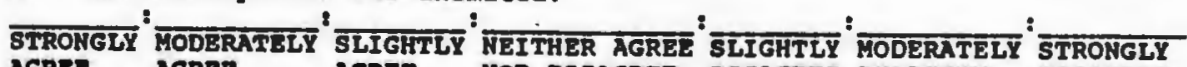
AGRE AGREE AGRE

10. Th1s salesperson was honest:

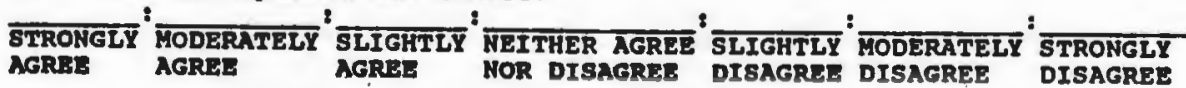

11. Th1: product represents a true Innovation for the music industry: STRONGLY
DISAGREE DISAGREE

12. Many people w111 want to buy this product: STRONGLY
AGREE

13. This aleeperson was an efective combunicator: STRONGLY
DISAGREE DISAGREE

14. Salespeople are basical1y helprul:

ETRONGLY ' MODERATELY ' SLIGHTLY ' NEITHER AGREL' SLIGHTLY ' MODERATELY ' STRONGLY $\begin{array}{lll}\text { AGREE AGREE AGREE NOR DISAGREE DISAGREE DISAGREE DISAGREE } & \end{array}$ 
15. The $11 k 1$ ihood that the customer in the tape bought the product Is: VERY ' WODERATELY ' SLIGHTLY' NEITHER LIKELY' SLIGHTLY MODERATELY ' STRONGLY LIKELY LIKELY LIKELY NOR UNLIKELY UNGIKELY UNLIKELY UNLIKELY

16. The interaction between the salesperson and the customer in the tape was very friendly.

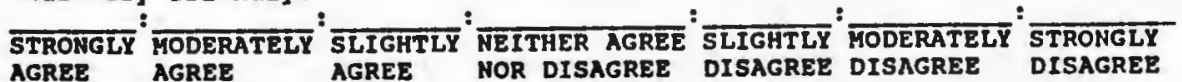

17. The interaction between the salesperson and the customer was very stralned

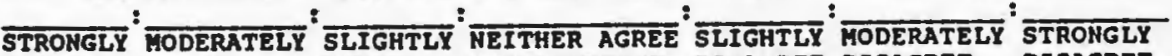
AGREE AGREE AGREE NOR DISAGRE DISAGREE DISAGREE DISAGREE

18. The Interaction between the salesperson and the customer in the Eape was very relaxed:

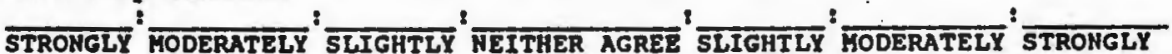
AGRE AGRE AGRE HOR DISAGRE DISAGRE DISAGREE DISAGREE

19. The salesperson tended to monopolize the conversation:

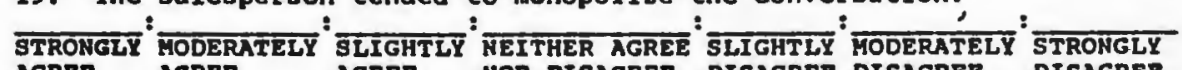
AGREE AGREE AGREE NOR DISAGREE DISAGREE DISAGREE DISAGREB

20. Once thia product is introduced In stores I w111 probably purchase one:

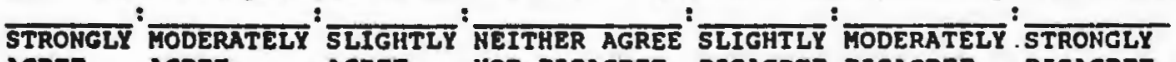
AGREE AGREE AGREE NOR DISAGREE DISAGREE DISAGREE DISAGREE

21. This product is especlally approprlate for college students:

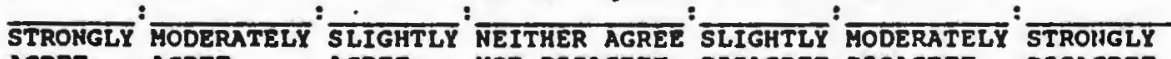
AGREE AGREE AGREE NOR DISAGREE DISAGREE DISAGREE DISAGREE

22. This salesperson was neryous:

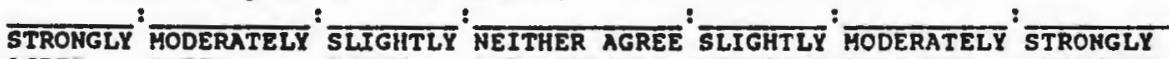
AGREE AGREE AGRE NOR DISAGREE DISAGREE DISAGREE DISAGREE

23. The salesperson in usually the type that I like to do bilatnans with:

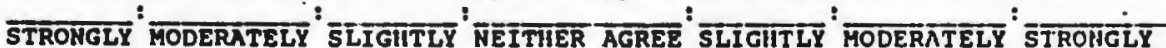
AGREE AGREE AGREE NOR DISAGREE DISAGREE DISAGREE DISAGREE

24. The salesperson was relaxed:

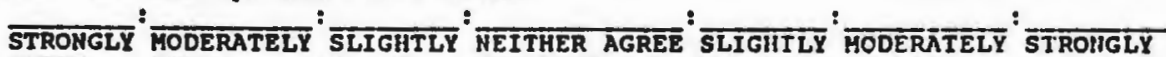
AGREE AGREE AGREE NOR DISAGREE DISAGREE DISAGREE DISAGREE

25. The likelihood that I would have bought this product from this salesperson 1s:

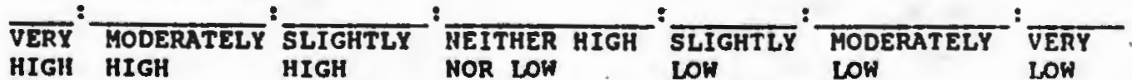

26. The salesperson in the tape was direct In answering the customer's questions.

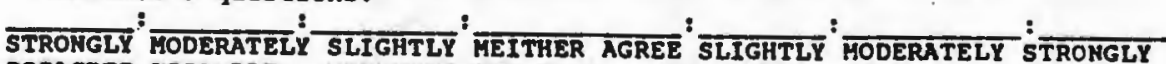
DISAGREE DISAGRE DISAGREE NOR DISAGREE AGREE AGREE AGREE.

27. This salesperson was cospetent:

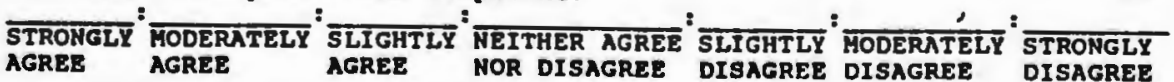

28. The salesperson was dramatic: इTRONGLY
AGREE 
29. This salesperson was intelligent.

STRONGLY " MODERATELY 'ं SLIGHTLY ' NEITHER AGREE ' SLIGHTLY 'MODERATELY ' STRONGLY AGREE AGREE AGREE NOR DISAGREE DISAGREE DISAGREE DISAGREE

30. The salesperson in the tape left me with a positive if -ission:

STRONGLY ' $\begin{array}{lll}\text { AGREE AGREE AGREE NOR DISAGREE DISAGREE DISAGREE DISAGREE } & \end{array}$

31. Once this product is in stores I w probably purchase one:

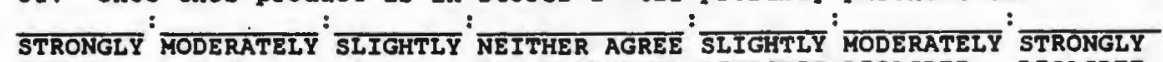
AGREE AGREE AGREE NOR DISAGREE DISAGREE DISAGREE DISAGREE

32. The salesperson was $r$, fcise:

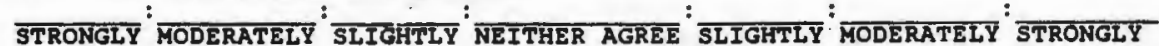
AGREE AGREE AGREE NOR DISAGREE DISAGREE DISAGRE .DISAGREE

33. Th1s salesperson was for -ndly:

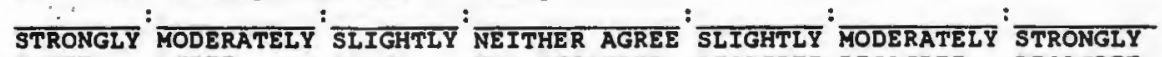
$\begin{array}{lll}\text { AGREE AGREE AGREE NOR DISAGREE DISAGREE DISAGREE DISAGREE } & \end{array}$

34. The customer in the ape was interested in what the salesperson had to say:

STRONGLY 'MODERATELY SLIGHTLY DISAGREE DISAGREE DISAGREE NOR DISAGREE AGREE AGREE 'AGREE

- 35. The salesperson was open:

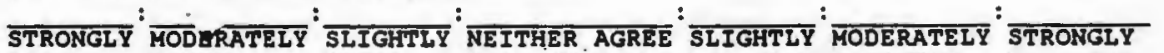
AGREE. AGREE AGREE NOR-DISAGREE DISAGREE DISAGREE DISAGREE

36. The salesperson was untentious: -

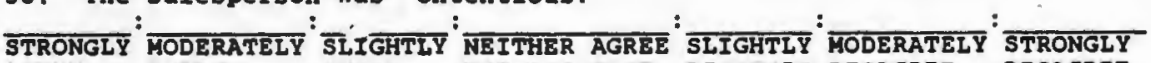
AGREE AGREE AGREE NOR DISAGREE DISAGREE DISAGREE DISAGREE

37. The sálesperson in the tape war spproachable:

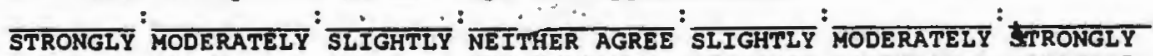
AGREE AGREE AGREE NOR DISAGREE DISAGREE DISAGREE DISAGREE

- 38. Tr. Salesperson in the tape was dominant:

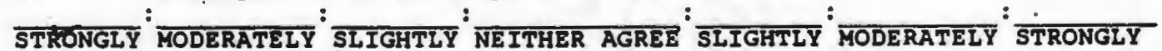
$\begin{array}{lll}\text { AGREE AGREE AGREE NOR DISAGREE DISAGREE DISAGREE DISAGREE } & \end{array}$

39. Th -salesperson in the tape was impression leaving:

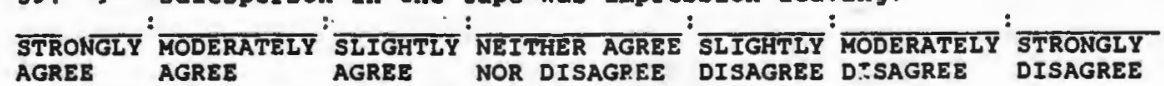

40. The salesp un in the tape was attentive:

STRONGLY ' AGRE AGRE AGRE NOR DISAGRE DISAGREE DISAGREE DISAGRE

41. I like whe salesperson takes a personal interest in me:

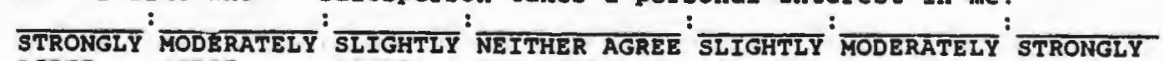
AGREE AGRE

42. I prefer $r$ to have a salesperson help me in evaluating a product:

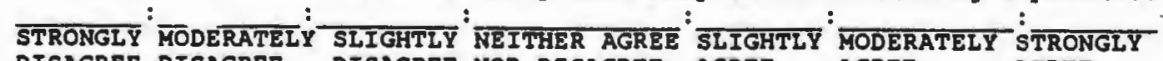
DISAGREE DISAGRE DISAGREE NOR DISAGREE AGREE AGREE AGREE 


\section{BIBLIOGRAPHY}

Bass, B. M. (1960). Leadership, Psychology, and Organizational Behavior. New York: Harper Bros.

Bass, B. M. (1967). Social behavior and the orientation inventory: A review. Psychological Bulletin, 68, 260-92.

Bednar, D. A. (1982). Relationships between communicator style and managerial performance in complex organizations: a field study. Journal of Business Communication, 19, 5175 .

Blake, R. R. , \& Mouton, J. S. (1980). The grid for sales excellence (2nd ed.). New York: McGraw-Hill.

Brock, T. C. (1965). Communicator-recipient similarity and decision change. Journal of Personality and Social Psychology, 1, 650-654.

Bushard, B. L. (1959). Methodology of the study. In K. L. Artis (ed), The symptom as communication in schizophrenia. New York: Grune \& Stratton.

Capon, N., Holbrook, M. B., \& Hulbert, J. M. (1977). Selling process and buyer behavior: Theoretical implications of recent research. In A. G. Woodside, J. N. Sheth \& P. D. Bennett (eds), Consumer and Industrial Buying Behavior. New York: Elsevier North Holland, Inc.

Evans, F. B. (1963). Selling as a dyadic relationship - a new approach. American behavioral scientist, $6,76-79$.

Hayes, D. , \& Meltzer, I. (1972). Interpersonal judgments based on talkativeness: fact or artifact. Sociometry, 35, 338-561.

Hulbert, James \& Capon, Noel (1972). Interpersonal communication in marketing: an overview. Journal of Marketing Research, 2, 27-34.

Mathews, H. L., Wilson, D. T., \& Monoky, J. F. (1972). Bargaining behavior in a buyer-seller dyad. Journal of Marketing Research, 2, 103-05.

Mortensen, D. A. (1972). Communication: The Study of Human Interaction. New York: McGraw-Hill Book Company.

Norton, R. (1977). Teacher effectiveness as a function of communicator style. In B. D. Ruben (ed.), Communication Yearbook I. New Brunswick: Transaction Books.

Norton, R. (1978). Foundation of a communicator style construct. Human Communication Research, 4, 99-112. 
Norton, R., \& Miller, L. (1975). Dyadic perception of communication style. Communication Research, $\underline{2}$, 50-67.

Norton, R. \& \& Pettegrew, L. S. (1977). Communicator style as an effect determinant of attraction. Communication Research, 4, 257-82.

Norton, R., Syphner, H., Clarke, C., \& Brady. (1977). Dimensions of a dramatic communicator style. Paper presented at the annual meeting of the speech Communication Association, Washington, DC.

Norton, R., Baker, N., Bednar, D., Sayler, R., \& McGough, T. (1978). Impressions of interpersonal dramatic style. Paper presented at the annual meeting of the speech communication Association, Minneapolis, MI.

Norton, R. \& Bednar, D. A., (1979). Ideal communicator style for the interviewee. Paper presented at the annual meeting of the International Communication Association, Philadelphia, PA.

Norton, R., \& Montgomery, B. (1979). An integration of style, content, and target in defining and measuring openness. Paper presented at the annual meeting of the International Communication Association, Philadelphia, PA.

Norton, R., \& Nussbaum, J. (1980). Dramatic behaviors of the effective teacher. In Nimmo, D. (ed.) Communication Yearbook. 4, New Brunswick: Transaction Books.

Norton, R. \& Miller, L. D. (1975). Dyadic perception of communication style. Communication Research, 2, 50-67.

Norton, R., Pettegrew, L. S., \& Land, S. (1975). Communicator style correlates of attraction. Paper presented to the International Communication Convention, Chicago.

Norton, R., \& Pettegrew, L. S. (1979). Attentiveness as a style of communication: A structural analysis. Communication Monographs. 46, 13-26.

Norton, R., \& Robinson, D. Communicator style in career decisions. Paper presented at the annual meeting of the Speech Communication Association. New York.

Pace, W. R. (1962). Oral communication and sales effectiveness. Journal of Applied Psychology, 44, 487-8.

Padgett, V. R., \& Wolosin, R. J. (1980). Cognitive similarity in dyadic communication. Journal of Personality and Social Psychology. 39, 654-9. 
Sheth, J. M. (1976). Buyer-seller interaction: A conceptual framework. Proceedings of the Association for Consumer Research. Cincinnati, OH: Association for Consumer Research, 382-6.

Staley, C. C., \& Cohen, J. L. (1988). Communicator style and social style: similarities and differences between the sexes. Communication Quarterly. In press.

Williams, K. C. \& Spiro, R. L. (1985). Communication style in the salesperson-customer dyad. Journal of Marketing Research. 22, 434-42.

Woodside, A. G. \& Davenport, W. J., (1974). The effect of salesmen similarity and expertise on consumer purchasing behavior. Journal of Marketing Research. 11, 198-202. 